\title{
触 New Disease Reports \\ First report of Tomato brown rugose fruit virus infecting tomato in Germany
}

W. Menzel ${ }^{1} *$, D. Knierim ${ }^{1}$, S. Winter ${ }^{1}$, J. Hamacher ${ }^{2}$ and M. Heupel $^{3}$

${ }^{1}$ Leibniz Institute DSMZ - German Collection of Microorganisms and Cell Cultures, Plant Virus Department, Inhoffenstraße 7 B, 38124 Braunschweig, Germany; ${ }^{2}$ University of Bonn, Department of Phytomedicine, Institute of Crop Science and Resource Conservation, Nußallee 9, 53115 Bonn, Germany; ${ }^{3}$ Landwirtschaftskammer Nordrhein-Westfalen, Pflanzenschutzdienst, Gartenstrasse 11, 50765 Köln-Auweiler, Germany

*E-mail: wulf.menzel@dsmz.de

Received: 23 Nov 2018. Published: 08 Jan 2019. Keywords: North Rhine-Westphalia, Solanum lycopersicum, Tobamovirus, ToBRFV

In July 2018, unusual fruit and leaf symptoms were observed in numerous greenhouses cultivating tomatoes commercially in the Lower Rhine region of North-Rhine Westphalia, Germany. Foliar symptoms included chlorosis, mosaic with dark green bulges and narrowing (Fig.1). Fruit symptoms consisted of yellow spots, often concentrated around the calyx (Fig. 2) with occasional rugose symptoms rendering the fruits non-marketable (Fig. 3). In total, more than 25 ha of greenhouse tomatoes were affected.

Initial investigation by electron microscopy showed the presence of filamentous virus-like particles, later identified as the Chile 2 strain of Pepino mosic virus (PepMV) and, in addition, particles with a tobamoviruslike structure. PepMV Chile 2 preparations are commonly used as inoculum for cross-protection against severe strains of PepMV, whereas infections with tobamoviruses are particularly rare since commercially grown tomato varieties harbour effective resistance genes (e.g. $T m-2^{2}$ ). RTPCR using a primer pair (514 Tobamos1: 5'-GGGAATCAGTTTCAAACRCA-3'; 515 Tobamoas1: 5'-GGGGGGATTCGAACCYCT-3') designed for universal detection of tobamoviruses (unpublished) resulted in amplicons of the expected size, c. $560 \mathrm{bp}$, for all symptomatic samples. Blastn analysis of the sequenced PCR products revealed $100 \%$ nucleotide identity (GenBank Accession Nos. KX619418 and KT383474) to Tomato brown rugose fruit virus (ToBRFV), a tobamovirus that was recently found in Jordan (Salem et al., 2016) and Israel (Luria et al., 2017). The resistance-breaking property of ToBRFV has already been observed by Luria et al. (2017) and was cited as the reason for the rapid spread of the virus in Israel, indicating the importance for commercial tomato cultivation worldwide. Total RNA preparations of two samples from Germany (P12-3G, P12-3H) were subjected to Illumina miSeq sequencing, revealing besides PepMV (MK133092 - P12-3G; MK133094 - P12-3H), the genome sequences of ToBRFV isolates (MK133093 - P12-3G; MK133095 - P12-3H) showing 99.6\% nucleotide sequence identity to each other. The sequence identities to the isolates from Jordan and Israel were in the same range (99.7-99.8\%) which points to a common origin.

ToBRFV was isolated from mixed infection with PepMV by passage on Chenopodium murale. The tomato plants subsequently inoculated with $C$. murale plant sap showed the same leaf symptoms as those originally observed (Fig. 4). The ToBRFV isolate P12-3G was deposited as PV-1236 in the DSMZ Plant Virus Collection. This is the first report of ToBRFV in Europe and outside countries of the Near East.

\section{References}

Luria N, Smith E, Reingold V, Bekelman I, Lapidot M, Levin I, Elad N, Tam Y, Sela N, Abu-Ras A, Ezra N, Haberman A, Yitzhak L, Lachman O, Dombrovsky A, 2017. A new Israeli Tobamovirus isolate infects tomato plants harboring $T m-22$ resistance genes. PLoS One 12, e0170429. http://dx.doi.org/10.1371/journal.pone.0170429

Salem N, Mansour A, Ciuffo M, Falk BW, Turina M, 2016. A new tobamovirus infecting tomato crops in Jordan. Archives of Virology $\mathbf{1 6 1}$ 503-506. http://dx.doi.org/10.1007/s00705-015-2677-7

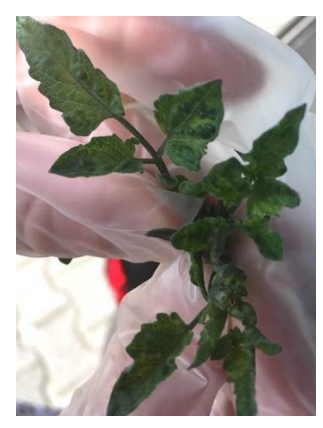

Figure 1

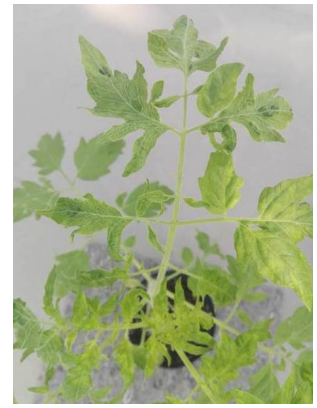

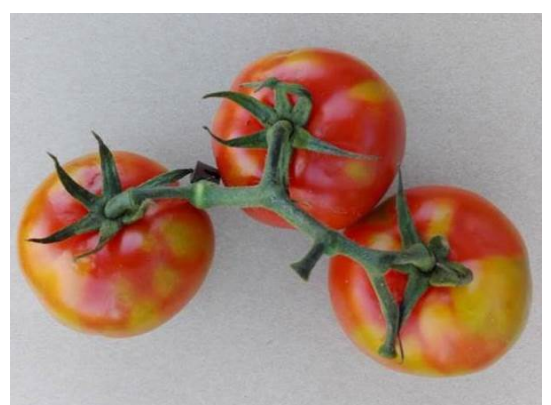

Figure 2

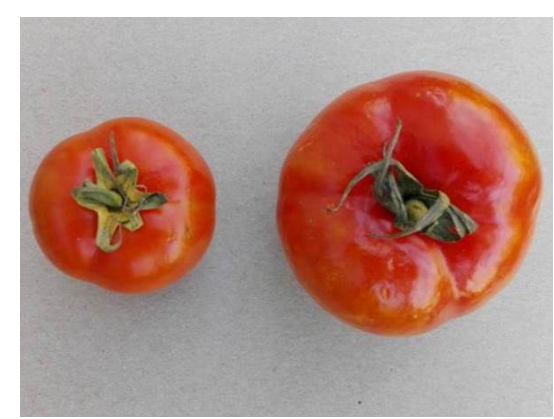

Figure 3

Figure 4

To cite this report: Menzel W, Knierim D, Winter S, Hamacher J, Heupel M, 2019. First report of Tomato brown rugose fruit virus infecting tomato in Germany. New Disease Reports 39, 1. http://dx.doi.org/10.5197/j.2044-0588.2019.039.001

(c) 2019 The Authors

This report was published on-line at www.ndrs.org.uk where high quality versions of the figures can be found. 